\title{
A PÁRKAPCSOLATI IDENTITÁS KÉRDŐÍV RELIABILITÁS- ÉS VALIDITÁSVIZSGÁLATA A KÉSZÜLŐDÓ FELNŐTTSÉG TÜKRÉBEN
}

\author{
Elekes Szende ${ }^{1}$, Komlósi Piroska², Szögeczki Sára ${ }^{3}$ \\ ${ }^{1}$ Sapientia Szerzetesi Hittudományi Főiskola, 1054 Budapest, Piarista köz 1.sz., \\ e-mail: elekes.szende@sapientia.hu \\ ${ }^{2}$ Károli Gáspár Református Egyetem, 1088 Budapest, Reviczky utca 4.sz., \\ e-mail: flaskom@t-online.hu \\ ${ }_{3}^{3}$ Pázmány Péter Katolikus Egyetem, BTK, Pszichológia Szak, e-mail: szogisari@gmail.com.
}

\begin{abstract}
Absztrakt
Háttér és célok: Napjainkban az identitás keresése kitolódik a húszas évek végéig (Arnett, 2000). Arnett ezt a sajátos, 19-29 év közötti időszakot „készülődő felnőttségnek" nevezi. A szakmai identitással ellentétben a párkapcsolati identitás kérdése eddig nem kapott hangsúlyt a szakirodalomban.

Jelen kutatás célja egy olyan mérőeszköz kialakítása, amely vizsgálja a „készülődő felnőttek” ideális párkapcsolati formával, elköteleződéssel kapcsolatos elképzeléseit.

Módszer: A Melgosa-féle Pályaidentitás Skála alapján kidolgoztuk a 20-itemes Párkapcsolati Identitás Kérdőívet (PIK). A konstruktumvaliditás mérése érdekében a Felnőtt Kötődés Skála (AAS), az Élet Értelme Kérdőív (MLQ), valamint az Élettel való Elégedettség Skála (SWLS) került felvételre, továbbá két item rákérdezett a vallásosságra. A vizsgálati mintát 405, 19-29 éves nem házas személy alkotta.

Eredmények: A főkomponens elemzés eredményei alapján a PIK három faktorát azonosítottuk, amelyek jó megbízhatósággal bírnak (Elköteleződés halogatása: $\alpha=0,864$; Családi mintakövetés: $\alpha=0,873$; Keresés és kétség: $\alpha=0,697$ ), és megfeleltethetők a Marcia-féle identitásállapotoknak. A statisztikai elemzés a diffúzió, valamint elért identitás itemeit egy faktorba sorolta. A faktorok gyenge vagy mérsékelt összefüggést mutatnak a felnőtt kötődés skála dimenzióival, az értelem jelenlétével és keresésével, az élettel való elégedettséggel és vallásossággal. Továbbá megállapítható, hogy a moratórium állapota az életkor előrehaladtával nem csökken, a diffúzió is csupán a nők esetén mutat csökkenést ( $\mathrm{r}=-0.227, \mathrm{p}<0,01)$, ami összhangban van Arnett elméletével.

Következtetések: A Párkapcsolati Identitás Kérdőív megbízható mérőeszköznek bizonyult, amely a Marcia-féle identitásparadima segítségével méri az egyének párkapcsolatokról alkotott elképzeléseit. További kutatásokra van szükség annak feltárására, hogy milyen összefüggés van a párkapcsolati identitás, valamint az identitás többi aspektusa között, és milyen tényezők állhatnak a különböző identitásállapotok hátterében.
\end{abstract}

Kulcsszavak: készülődő felnőttség • identitásállapotok • párkapcsolati identitás

\begin{abstract}
Background and purpuse: Nowadays, search for an identity and commitment is postponed until the late twenties. This period between 19-29 years is called „emerging adulthood" (Arnett, 2000). So far, relationship identity has been neglected in identity
\end{abstract}


literature. We aimed to construct an instrument that measures emerging adults' conceptions about ideal relationship forms and commitment.

Method: Based on Melgosa Occupational Identity Scale, we constructed Relationship Identity Questionnaire. In order to test construct validity, we applied Adult Attachment Scale (AAS), Meaning in Life Questionnaire (MLQ), Satisfaction with Life Scale (SWLS). Two items measured religious involvement. The sample included 405, 19-29 years old young people, who were not married yet.

Results: Principal component analysis identified three factors that show good reliability indices (Postponing of commitment: $\alpha=0,864$; Family patterns: $\alpha=0,873$; Search and doubts: $\alpha=0,697)$, that overlap with Marcia's identity statuses. The factor analysis included diffusion and achievement in one factor. The factors of RIQ show weak or moderate correlations with attachment styles, presence and search for meaning, satisfaction with life and religious involvement. Moratorium does not decrease with age, diffusion decreases only among women $(r=-0.227, p<0,01)$, that is in accordance with Arnett's theory.

Conclusion: RIQ is a reliable instrument to measure one's conceptions and attitudes toward relationships applying Marcia's identity paradigm. There is a need for further research in order to examine relationship with other aspects of identity (e.g. occupational identity) or to explore antecedents of these identity statuses.

Keywords: emerging adulthood • identity statuses • relationship identity

\section{BEVEZETÉS}

Erikson identitáselmélete (Erikson, 1959) óta számos átalakuláson mentek át az iparosodott társadalmak. A felsőfokú tanulmányok egyre több fiatalt érintenek, ezzel összefüggésben kitolódott a házasságkötés, valamint az első gyerek születésének időpontja (United Nations Economic Comission for Europe, 2013). Ezek a demográfiai változások kihatással vannak az identitáskeresés, valamint az elköteleződés pszichológiai folyamataira.

\subsection{Elméleti háttér: Erikson, Marcia, Arnett}

Erikson elmélete az identitáskeresés életfeladatát elsősorban a serdülőkorra datálja: az életszakasz végére a fiatal jó esetben elkötelezi magát bizonyos identitások mellett a társadalmi és magánéleti szférában egyaránt. Marcia továbbgondolta Erikson elméletét, és két szempontot figyelembe véve - volt-e krízis/ exploráció, illetve történt-e elköteleződés - négy identitásállapotot azonosított: identitásdiffúzió, korai zárás, moratórium, elért identitás (Marcia, 1966). Waterman (1985, idézi Cole \& Cole, 2006) kutatásai szerint az életkorral egyre csökken az identitásdiffúzióban lévők, ill. egyre nő az érett identitást elérők aránya.

Erikson mindemellett megjegyzi, hogy a fejlett nyugati társadalmak lehetôvé tesznek egy elhúzódó „pszichoszociális moratóriumot” a huszas évek közepéig, amely során a fiatal folytathatja az explorációt (Arnett, 2000). 
Az elmúlt évtizedek társadalmi változásaira hivatkozva Jeffrey Arnett a „készülődő felnőttség” kifejezést javasolja a 18-27 éves periódus megragadására, amellett érvelve, hogy egy különálló életszakaszról van szó, ami már nem serdülőkor, de még nem fiatal felnőttkor. Arnett szerint a készőlődő felnőttség sajátossága, hogy nincsenek kötelező jellegü normatív előírások, a fiatal folytathatja az explorációt szakmai és magánéleti téren egyaránt az elköteleződés sürgetése nélkül, valamint a szubjektív önjellemzésekben megjelenik az ún. „kettő-köztiség” élménye: az érintettek sem gyereknek, sem felnőttnek nem tekintik magukat (Arnett, 2000). Az életszakasz minden pozitívuma mellett az érem másik oldalán azt találjuk, hogy sokan beleragadnak az identitásdiffúzió vagy moratórium állapotába, akár szakmai, akár magánéleti téren, és halogatják az elköteleződés meglépését.

\subsection{Az identitás összefüggése más tényezőkkel}

A teljesség igénye nélkül fontos rávilágítani, hogy a szakirodalomban milyen tényezőkkel hozták összefüggésbe az identitást.

Számos kutatás rávilágított az identitás és kötődés kapcsolatára, ezen belül is a biztonságos kötődési minta és elért identitás közti összefüggésre (Palladino Schultheiss \& Bluestein, 1994; Faber, Edwards, Bauer \& Wetchler, 2003; Ratner, 2014; Sheng, 2014 stb). A biztonságos kötődés talaján a gyermek bátorságot meríthet az eltávolodáshoz, a környezet felderítéséhez, később ugyanígy képessé válik a pszichológiai explorációra, a különböző identitások melleti autonóm döntésre. Arseth és munkatársai metaanalízise szerint (2009, idézi Kroger \& Marcia, 2011), mely 14 kutatást vesz alapul, az elért identitás és a korai zárás egyaránt enyhe pozitív összefüggést mutat a biztonságos kötődéssel, míg a moratórium és diffúzió negatív összefüggésben van ugyanezzel. A párkapcsolati identitás szempontjából a kötődési stílus különösen fontos konstruktumnak bizonyulhat.

A szakirodalom tanúsága alapján az identitás összefüggést mutat az értelmesség-érzéssel is. Kiang és Fuligni (2010) azt találták, hogy az elért etnikai identitás összefügg az értelmesség-érzéssel és jólléttel. Ezzel szemben az élet értelmének keresése az élet kritikus időszakaiban merül fel (Frankl, 2005). Emiatt feltételezhető, hogy a moratóriumban lévő személyeknél intenzívebben jelentkezik az értelem keresése, szemben a korai zárókkal és elért identitású személyekkel.

Az identitás és a jóllét kapcsolatát szintén több vizsgálat (Schwartz és mtsai, 2011, 2013 stb.) is megerősítette: Schwartz, Zamboanga, Luyckx Meca és Ritchie (2013) a készülődő felnőttség korában lévő személyeket vizsgálva azt találták, hogy az elért identitás pozitív, míg az identitásdiffúzió negatív kapcsolatban áll

feeling in-between 
a jólléttel, az értelmesség-érzésének megélésével, valamint az élettel való elégedettséggel.

Végül, de nem utolsó sorban összefügést találtak a vallásosság és a különböző identitásállapotok között is. Egy kutatás szerint az elért identitású és a korai záró serdülők sokkal rendszeresebben járnak templomba, mint a moratórium és az identitásdiffúzió állapotában lévő személyek (Markstrom, Hofstra \& Dougher, 1994). Markstrom (1999) továbbá azt találta, hogy azok a serdülők, akik valamilyen szinten bevonódtak a vallási életbe (pl misére vagy Biblia-körre jártak), sokkal erősebb ego-státusszal rendelkeztek a remény, akarat, a hűség, a szeretet és a célok elérése terén.

\subsection{Az identitás mérésére használt eszközök}

Erikson és Marcia elméletére alapozva számos méreőeszközt dolgoztak ki az identitás különböző vetületeinek vizsgálatára; a teljesség igénye nélkül bemutatunk néhányat a fontosabbak közül. Az elsők között volt a 64 tételből álló Objective Measure of Ego Identity Status (Bennion \& Adams, 1986), amely a négy identitásállapotnak megfelelően kérdez rá az egyén szakmával kapcsolatos, vallási és politikai nézeteire.

Az OM-EIS alapján készítette el Grotevant és Adams az Extended Objective Measure of Ego Identity Status skálát (EOM-EIS, Balistreri, Busch-Rossnagel \& Geisinger, 1995), amely az előző három terület mellett rákérdez a baráti és szexuális kapcsolatokról való gondolkodásra, randevúzási szokásokra, életmóddal kapcsolatos nézetekre is.

Napjainkban az egyik legismertebb mérőeszköz az Ego Identity Process Questionnaire (EIPQ, Balistreri és mtsai, 1995). A skála 32 tétele két dimenzió mentén - krízis és elköteleződés - mér, és az élet nyolc területéhez kapcsolódóan tesz föl kérdéseket: munka, vallási és politikai nézetek, értékek, család, baráti kapcsolatok, randevúzási szokások, szexualitáshoz való viszonyulás.

A Melgosa-féle Pályaidentitás Skála (OIS, Melgosa, 1987; Andrási, 1995) szintén a Marcia-féle identitásállapotokra épül, azonban ő kifejezetten a szakmával szembeni elköteleződést vizsgálta.

\subsection{A párkapcsolati identitás problémája}

A fentebb végig tekintett mérőeszközök az identitást általában véve a pályaválasztás, vallási és politikai nézetek, baráti kapcsolatok esetén vizsgálják. A kérdőívek tételei között fellelhetünk párat, amelyek az egyén kapcsolataira, szexuális életére, nemi szerepekkel kapcsolatos nézeteire vonatkoznak, mint pl.: „Nem vagyok benne biztos, hogy milyen a számomra ideális párkapcsolati forma.” („I 
am not sure about what type of dating relationship is best for me."), "Bizonyos tapasztalatok hatására átalakultak a férfi-női szerepekkel kapcsolatos nézeteim” ("I have undergone several experiences that made me change my views on men's and women's roles") (Balistreri és mtsai, 1995). Megállapítható azonban, hogy kimondottan a párkapcsolati formákra vonatkozó exploráció és elköteleződés az identitásvizsgálatok során háttérbe szorult, a párkapcsolati identitást kifejezetten semmilyen eszköz nem méri, holott egy egyetemi hallgatók körében végzett vizsgálat tanulsága szerint a párkapcsolatokat jelölik meg életük legnagyobb krízisének a készülődő felnőttség szakaszában lévő személyek (Kézdy, 2007).

Ezért értékeltük úgy, hogy a párkapcsolati identitás vizsgálatára is érdemes lenne egy kérdőivet létrehozni. A mérőeszköz még nem házasságban élő személyek párkapcsolati elköteleződéssel kapcsolatos elképzelését vizsgálja. Nem a konkrét partnerekkel szembeni elköteleződés kérdése van a fókuszban, hanem annak vizsgálata, hogy a személy mennyire alaposan gondolkodik azon, hogy mi a számára ideális párkapcsolati forma (moratórium) vagy sodródik egyik napról a másikra (diffúzió), kész-e a jövőbeni elköteleződésre, és ha igen, milyen motivációból: családja hatására, mert „ez a szokás” (korai zárás) vagy egyéni átgondolás következtében (elért identitás). Az elköteleződést a házasságkötéssel azonosítottuk, mert a szakirodalom tanúsága szerint, ez a legjelentősebb és legkonkrétabb gesztus, amely a külvilág felé is kinyilvánítja az elköteleződést egy párkapcsolatban (Kopp \& Skrabski, 2006; Horváth-Szabó, 2007).

\subsection{Célkitúzések}

I. Pszichometriai mutatók vizsgálata: az újonnan létrehozott párkapcsolati identitást mérő eszköz faktorstruktúrájának,valamint megbízhatóságának vizsgálata.

II. Konstruktumvaliditásra vonatkozó célkitüzések: az újonnan kialakított kérdőív és különböző változók (kötődési stílusok, az élet értelmének jelenléte és keresése, az élettel való elégedettség stb) közötti összefüggések feltárása.

\subsection{Hipotézisek}

I. A skála pszichometriai mutatóira vonatkozó hipotézis:

1. A skála belső struktúráját négy faktor fogja megadni a Marcia-féle négy identitásállapotnak megfelelően; így feltételezhetően a négy faktor az elért identitás, a korai zárás, a moratórium, valamint az identitásdiffúzió lesznek. 


\section{A skála konstruktumvaliditására vonatkozó hipotézisek:}

1. A párkapcsolati identitás faktorai és a kötődési stílusok (biztonságosan, ambivalens, elkerülő kötődésekkel) között összefüggést várunk: a biztos kötődés pozitívan fog korralálni az elért identitással és korai zárással, negatívan a moratóriummal és diffúzióval.

2. Az élet értelmének megélése és az elért identitás között, valamint az élet értelmének keresése és a moratórium között összefüggést várunk.

3. Az elért identitás pozitív kapcsolatban áll az élettel való elégedettséggel.

4. Az életkor előrehaladtával a moratórium, valamint az identitásdiffúzió állapotában lévők száma csökkeni, míg az elért identitásállapotú személyek száma nőni fog.

5. A párkapcsolati státusz (egyedülálló, párkapcsolatban él, élettársi kapcsolatban él) és az identitásállapotok között összefüggést várunk.

6. A vallás szubjektív fontossága, valamint a vallásgyakorlás rendszeressége pozitívan fog korrelálni az elért identitással, valamint a korai zárással.

\section{MÓDSZER}

\subsection{Vizsgálati személyek}

A mintát a készülődő felnőttség elmélete (Arnett, 2000) alapján olyan 19-29 év közötti fiatal felnőttek alkották, akik még nem kötöttek házasságot, tehát vagy egyedülállók, vagy párkapcsolatban, esetleg élettársi kapcsolatban élnek. A mintavételi eljárás nem valószínűségi mintavétellel, hólabda módszerrel történt. A kutatásban 408 fő vett részt, közülük azok eredményei kerültek bele a végleges mintába, akik megfeleltek az életkori, családi állapot feltételeinek, valamint minden kérdésre választ adtak. Az előbb említett kritériumoknak három fő nem felelt meg, így a végleges minta 405 fóből állt.

\subsection{Eljárás}

\section{A skála kidolgozásának folyamata}

A kérdőív alapjául a Melgosa-féle Pályaidentitás Skála szolgált. Ez a skála a Marcia-féle négy identitásállapotra épül, azok adják a tételek alskáláit. Az újonnan létrehozott párkapcsolati identitást mérő kérdőív tételei a Pályaidentitás Skála tételeinek átfogalmazása révén jöttek létre (pl.: a Pályaidentitás Skála egy tétele: „Nincs határozott elképzelésem arról, hogy mi lesz a foglalkozásom, de nem is igazán érdekel.”, az átalakított párkapcsolati identitásra rákérdező tétel: „Nincs határozott elképzelésem arról, hogy hogy alakul a magánéletem a jövő- 
ben, de nem is érdekel.”). Az eredeti 28 tételből 17-et használtunk fel, amit kiegészítettünk további három tétellel. A skála bemérését megelőzően pilóta-tanulmányt végeztünk. A mérőeszközt kiküldtük húsz személynek, majd az ő viszszajelzéseik alapján átfogalmaztunk három tételt, amelyek megfogalmazása kevésbé volt világos a kitöltők számára (pl. az összetett mondatokat egyszerűsítettük az érthetőség érdekében).

\section{Adatfelvétel}

Az adatok felvétele 2016 március-áprilisában történt. A kérdőívet a személyek a kerdoivem.hu online felületen töltötték ki. A kutatás az etikai irányelveknek megfelelően zajlott. A kérdőívcsomag kitöltése előtt a részvevők részletes tájékoztatót kaptak a kutatás menetéről, anonimitásáról, az adatok bizalmas kezelésének módjáról. A személyek önként, saját beleegyezésük hozzájárulásával töltötték ki a kérdőívcsomagot. Az e-mail címünk megadásával a személyeknek lehetőséget nyújtottunk bármilyen felmerülő kérdés, visszajelzés megfogalmazására, továbbá a vizsgálatot a kitöltés során bármikor megszakíthatták. A kitöltés megközelítőleg 20-25 percet vett igénybe.

\subsection{Mérőeszközök}

Párkapcsolati Identitás Kérdőív (PIK): az általunk létrehozott mérőeszköz a Marcia-féle identitáselméleti keretre épül, alapját a Melgosa-féle Pályaidentitás Skála szolgáltatta (Melgosa, 1987; Andrási, 1995). A válaszadóknak egy 5 fokú Likert-skálán (1-egyáltalán nem igaz, 2-inkább nem igaz, 3-nem tudom eldönteni, 4-inkább igaz, 5-nagyon igaz) kell eldönteniük, hogy mennyire tartják igaznak magukra nézve az állításokat.

Felnőtt kötődés skála (AAS, Collins \& Read, 1990; magyar változat: 75 papír-ceruza teszt): A kérdőív Hazen és Shaver (1987) által megállapított kötődési stílusok három dimenziójából - biztonságos, elkerülő és szorongó/ambivalens - épül fel. Mindhárom alskála megbízhatósága az elfogadható tartományba esik ( $a=0.69, a=0.72$, ill. $a=0.75$ ). A vizsgálati személyeknek egy 5 fokú Likert skálán kell válaszolniuk ( $0=$ egyáltalán nem, $4=$ nagyon).

Élet Értelme Kérdőív (MLQ, Steger \& Frazier, 2006; Martos \& Konkoly-Thege, 2012): az MLQ két alskálán keresztül méri az értelem jelenlétét, valamint az értelem keresését. A személynek egy 7 fokú Likert skálán (1-egyáltalán nem igaz, 7-tökéletesen igaz) kell eldöntenie, mennyire ért egyet a merőeszköz tíz állításával, például: „Az életemnek világos célja van.” (értelem jelenléte); „Állandóan valami olyat keresek, amitől fontosnak érezhetem az életemet." (értelem keresése). A megbízhatósági mutatói a=0.79-0.89 közötti értéket vettek fel (Martos \& Konkoly-Thege, 2012). 
Élettel való Elégedettség Skála (SWLS, Diener és mtsai, 1985; Martos, Sallay, Désfalvy, Szabó \& Ittzés 2014): Ezt az 5 tételből álló skálát „a leggyakrabban alkalmazott jóllét-kérdőívként” tartják számon (Martos és mtsai, 2014). A kitöltőnek egy 7 fokú skálán kell megjelölnie, mennyire ért egyet a felsorolt állításokkal (pl.: „Ha újra élhetném az életemet, nem változtatnék szinte semmit.”). A kérdőív megbízhatósága kitűnőnek bizonyult $(a \geq 0,84)$.

Demográfiai adatok: a kérdőívcsomag tartalmazta néhány általános demográfiai adat (nem, életkor, lakhely, iskolai végzettség, párkapcsolati státusz) lekérdezését is. Továbbá a Hungarostudyból (Kopp \& Kovács, 2006) átvett két tétel rákérdezett a vallásgyakorlás gyakoriságára („Gyakorol-e Ön valamilyen vallást, és ha igen, milyen rendszerességgel?”), illetve a vallás szubjektív fontosságára („Mennyire fontos Önnek a mindennapi életében a vallás?”).

\subsection{Statisztikai módszerek}

Az adatok statisztikai elemzését az SPSS.22. program segítségével végeztük.

A ferdeség és a csúcsosság vizsgálata alapján megállapítható, hogy az esetek többségében a normalitás feltétele nem teljesül (1. 1. táblázat).

1. tábl. A ferdeség és csúcsosság értékei a vizsgált alskálákon

\begin{tabular}{lcccc}
\hline & \multicolumn{2}{c}{ Ferdeség } & \multicolumn{2}{c}{ Csúcsosság } \\
\cline { 2 - 5 } PIK-EH & Statistic & Stand.hiba & Statistic & Stand.hiba \\
\cline { 2 - 5 } PIK-KK & .810 & .121 & -.346 & .242 \\
PIK-CsM & .572 & .121 & -.440 & .242 \\
AAS-S & -.148 & .121 & -1.064 & .242 \\
AAS-Av & -.198 & .121 & -.218 & .242 \\
AAS-Ax & .318 & .121 & -.291 & .242 \\
MLQ-PM & .458 & .121 & -.294 & .242 \\
MLQ-SM & -.670 & .121 & -.193 & .242 \\
SWLS & -.833 & .121 & .666 & .242 \\
\hline
\end{tabular}

Miután azonban - egyetlen kivételtől eltekintve - mind a ferdeség, mind a csúcsosság a -1 és +1 közötti intervallumban van, a normalitás nem sérül olyan mértékben, hogy ez várhatóan nagy mértékben befolyásolná a vizsgálati eredményeinket. Azonban a sérülések miatt paraméteres tesztjeinket (Pearson- 
korrelációk, T-próba és varianciaanalízis) minden esetben a megfelelő, nemparaméteres alternatívákkal is teszteltük (Spearman-korreláció, Kruskal Wallis, Mann Whitney-teszt) (lásd például Varga, 2015; Takács, 2012; Takács, 2016). A következőkben a paraméteres tesztek eredményeit közöljük, mivel mind a paraméteres, mind pedig a nemparaméteres tesztek eredményei egybehangzóan, azonos irányú kapcsolatokat tártak fel a változók/csoportok között.

\section{EREDMÉNYEK}

\subsection{Leíró statisztika}

A nemek eloszlása tekintetében a minta megközelítőleg kiegyensúlyozott, hozzávetőleg ugyanannyi nő (54\%, 220 fó) van, mint férfi (46\%, 185 fö). A korosztályok eloszlásában egy torzítást láthatunk a 20-24 évesek irányába (64\%), a 19, valamint 25-29 évesek a mintának kisebb hányadát (36\%) alkotják (átlagéletkor $=23$ év, $\mathrm{SD}=2,76$ ).

A családi állapot tekintetében elmondható, hogy az egyedülállók (50\%, 203 fó) a párkapcsolatban élőkhöz (44\%, 179 fó) és élettársi kapcsolatban élőkhöz (6\%, 23 fó) képest pont fele arányban vettek részt a vizsgálatban.

A felhasznált mérőszközök megbízhatóságának vizsgálata céljából minden mérőeszköz esetén Cronbach-alfa értéket számoltunk. Ezek az értékek minden alskála esetén nagyjából megegyeznek az eredeti kutatásokkal, kivéve a Felnőtt Kötődés Skála Biztos kötődés (S) alskálája, amely jelentősen eltér negatív irányban az eredetitől $(a=0,315)$. A 2.táblázat összefoglalását nyújtja a mérőeszközök leíró statisztikájának.

2. tábl. A használt mérőeszközök leíró statisztikája

\begin{tabular}{lcccccc}
\hline & átlag & SD & standard hiba & min & max & Cronbach-alfa \\
AAS - S & 18,67 & 3,30 & 0,16 & 9 & 26 & $\mathbf{0 , 3 1 5}$ \\
\hline AAS - Av & 15,72 & 4,76 & 0,24 & 6 & 29 & $\mathbf{0 , 7 1 4}$ \\
\hline AAS - Ax & 16,14 & 4,48 & 0,22 & 7 & 30 & $\mathbf{0 , 6 3 1}$ \\
\hline MLQ - PM & 24,92 & 7,26 & 0,36 & 5 & 35 & $\mathbf{0 , 9 1 5}$ \\
MLQ - SM & 24,54 & 6,22 & 0,31 & 5 & 35 & $\mathbf{0 , 7 6 1}$ \\
\hline SWLS & 24,42 & 6,21 & 0,31 & 5 & 35 & $\mathbf{0 , 8 2 8}$ \\
\hline
\end{tabular}




\subsection{Faktoriális érvényesség vizsgálata}

Faktoranalízissel vizsgáltuk, hogy az általunk létrehozott Párkapcsolati Identitás Kérdőív milyen alskálákra bontható. A dimenzióredukció módszereként főkomponens-elemzést végeztünk Varimax-forgatással. A kialakult alskálákat az orthogonalitást biztosító Anderson-Rubin módszerrel mentettük ki. A KayserMayer-Olkin érték alapján az elemszám megfelelő, a főkomponens eredményei értelmezhetőek $(\mathrm{KMO}=0,904)$. A Bartlett teszt alapján, mely az itemek teljes függetlenségét teszteli, feltételezhetjük, hogy az itemek között megfelelően erősek a korrelációk $\left(\chi^{2}(\mathrm{df}=190 \mathrm{~N}=405)=3470,856 \mathrm{p}<0,01\right)$.

A létrejövő főkomponensek közül a Kaiser-kritérium alapján azokat tartottuk meg, amelyeknek sajátértéke egy fölött van. Az így kapott négy komponens az itemek varianciájának 58,909\%-át magyarázza. A 3.táblázat tartalmazza a komponensek forgatás előtti és azt követő saját értékeit, valamint az általuk megmagyarázott varianciát. A választott kritériumszint helyességét a Scree-plot is alátámasztja (1.ábra).

3. tábl. A komponensek által megmagyarázott variancia rotáció előtt és után

\begin{tabular}{ccccc}
\hline & \multicolumn{2}{c}{ Forgatás elött } & \multicolumn{2}{c}{ Forgatás után } \\
\hline Komponens & Sajátérték & $\begin{array}{c}\text { Megmagyarázott } \\
\text { variancia (\%) }\end{array}$ & Sajátérték & $\begin{array}{c}\text { Megmagyarázott } \\
\text { variancia (\%) }\end{array}$ \\
\hline 1 & 6,899 & 34,497 & 4,250 & 21,248 \\
2 & 2,247 & 11,234 & 3,672 & 18,359 \\
3 & 1,501 & 7,506 & 2,359 & 11,794 \\
4 & 1,134 & 5,672 & 1,502 & 7,509 \\
\hline
\end{tabular}

Kaiser kritérium alapján megtartott komponensek. A kumulált megmagyarázott variancia 58,909\%.

1. ábra. Komponensek sajátérték szerinti csökkenő sorrendben

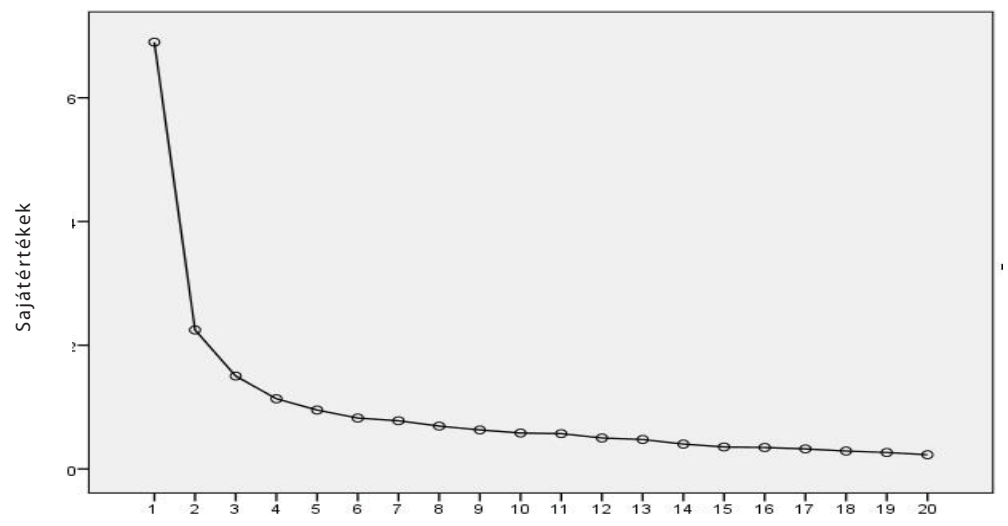


Az orthogonális forgatást követő komponensstruktúrát a 4.táblázat foglalja össze. Az értelmezhetőség érdekében egy tengelyhez csak azokat az itemeket jelenítettük meg, melyek az adott tengelyre $b_{s}=0,4$-es érték fölött töltenek. Ez 16\%-os magyarázóerőt jelent.

4. tábl. A húsz item komponenstöltés-értékei a forgatást követően

\begin{tabular}{|c|c|c|c|c|}
\hline Tétel/Főkomponens & 1 & 2 & 3 & 4 \\
\hline $\begin{array}{l}\text { Jelen pillanatban nem izgat, hogy akarok-e házasságot kötni, majd a jövő- } \\
\text { ben gondolkodom rajta. }\end{array}$ & 0,756 & & & \\
\hline $\begin{array}{l}\text { Bár még nem világos számomra, hogy milyen párkapcsolati formában sze- } \\
\text { retnék élni, ez most még nem izgat. }\end{array}$ & 0,729 & & & \\
\hline Túl korai számomra, hogy a házasságkötés lehetőségén gondolkodjam. & 0,718 & & & \\
\hline $\begin{array}{l}\text { Miután alaposan gondolkodtam a szóba jöhető párkapcsolati formákon, } \\
\text { arra jutottam, hogy a házasság a lehető legjobb ezek közül. }\end{array}$ & $-0,666$ & & & \\
\hline Arra a következtetésre jutottam, hogy szeretnék házasságot kötni a jövőben. & $-0,656$ & 0,406 & & \\
\hline $\begin{array}{l}\text { Miután sokat töprengtem rajta, megbizonyosodtam arról, hogy szeretnék } \\
\text { házasságot kötni. }\end{array}$ & $-0,638$ & & & \\
\hline $\begin{array}{l}\text { Nincs határozott elképzelésem arról, hogy hogy alakul a magánéletem a } \\
\text { jövőben, de nem is igazán érdekel. }\end{array}$ & 0,589 & & & \\
\hline $\begin{array}{l}\text { Nem okoz hosszas töprengést, hogy milyen párkapcsolati formában szeret- } \\
\text { nék élni, mert a családi hagyományt követem. }\end{array}$ & & 0,864 & & \\
\hline Szeretnék megházasodni, mert a családomban ez a hagyomány. & & 0,834 & & \\
\hline A szüleim példája nyomán én is meg szeretnék házasodni. & & 0,793 & & \\
\hline $\begin{array}{l}\text { Nem gondolkoztam túl sokat azon, hogy érdemes-e házasságot kötni, mert } \\
\text { a szüleim már gyerekként erre neveltek. }\end{array}$ & & 0,787 & & \\
\hline $\begin{array}{l}\text { Már gyermekkoromban eldöntöttem, hogy házasságot szeretnék kötni, soha } \\
\text { nem gondoltam más lehetőségre. }\end{array}$ &,- 410 & 0,592 & & \\
\hline $\begin{array}{l}\text { Sokat gondolkodom azon, hogy milyen párkapcsolati forma a legjobb szá- } \\
\text { momra. }\end{array}$ & & & 0,763 & \\
\hline $\begin{array}{l}\text { Az aktuális párkapcsolatom mellett nyitva tartom a szemem, és érdeklődöm } \\
\text { más potenciális romantikus partnerek iránt is. }\end{array}$ & & & 0,630 & \\
\hline $\begin{array}{l}\text { Próbálom eldönteni, hogy milyen párkapcsolati forma tudna boldoggá ten- } \\
\text { ni hosszú távon, de még nem jutottam semmire. }\end{array}$ & 0,434 & & 0,617 & \\
\hline $\begin{array}{l}\text { Komolyan foglalkoztat, hogy megtalálom-e életem párját: sok kételyem van } \\
\text { ezzel kapcsolatban. }\end{array}$ & & & 0,551 & 0,434 \\
\hline $\begin{array}{l}\text { Jelenleg nem tudom pontosan, hogy kössek-e házasságot vagy sem; néha } \\
\text { megfordul a fejemben a lehetőség. }\end{array}$ & & & 0,529 & \\
\hline $\begin{array}{l}\text { Ha nem látok perspektívát abban a párkapcsolatban, amiben vagyok, nem } \\
\text { fogok sokat töprengeni azon, hogy kilépjek-e belőle. }\end{array}$ & & & & 0,720 \\
\hline Nem nyugszom addig, amíg meg nem találom életem párját. & & & & 0,657 \\
\hline $\begin{array}{l}\text { Szerintem az ember tegyen meg minden tőle telhetőt, hogy megtalálja éle- } \\
\text { te párját. }\end{array}$ & $-0,437$ & & & 0,446 \\
\hline
\end{tabular}


Az első komponenst hét item alkotja. Az itemek közül négy a párkapcsolati elköteleződés hiányára vonatkozik ( identitásdiffúzió), három item pedig a párkapcsolati elköteleződésre vonatkozó szándékot méri ( elért identitás). Ebben a faktorban az utóbbi három tétel fordított itemként szerepel, így ez a három is az elköteleződés hiányát mutatja. Olyan állítások tartoznak ide, mint „Túl korai számomra, hogy a házasságkötés lehetőségén gondolkodjam.” vagy „Arra a következtetésre jutottam, hogy szeretnék házasságot kötni a jövőben.” (fordított tétel). A komponenst Elköteleződés halogatásának (EH) neveztük el. A komponens reliabilitása jónak tekinthető $(a=0,864)$.

A második komponens öt itemet tartalmaz, amelyek tartalmilag a házasságot mint a szülők mintájából átvett elköteleződési formát írják le ( korai zárás). Példa az itemekre: „Szeretnék megházasodni, mert a családomban ez a hagyomány.” vagy „Nem gondolkoztam túl sokat azon, hogy érdemes-e házasságot kötni, mert a szüleim már gyerekként erre neveltek.”. A komponens a Családi mintakövetés ( $C s M$ ) nevet kapta, megbízhatósága szintén jónak tekinthető $(a=0,873)$.

A harmadik komponens szintén öt itemet tartalmaz. Az itemek tartalmilag az ideális párkapcsolati formának a keresését, azzal kapcsolatos kétségeket, bizonytalanságokat fogalmazzák meg ( moratórium). Olyan tételeket tartalmaz, mint például: „Sokat gondolkodom azon, hogy milyen párkapcsolati forma a legjobb számomra.” vagy „Komolyan foglalkoztat, hogy megtalálom-e életem párját: sok kételyem van ezzel kapcsolatban.”. A komponenst Keresés és kétség (KK) alskálának neveztük el, reliabilitása elfogadhatónak mondható ( $\mathrm{a}=0,697)$.

A negyedik komponens három itemet tartalmazott. A három tétel az elköteleződési szándék meglétére vonatkozott, ám tartalmilag nem illett a többi tételhez, valamint a komponens megbízhatósága elfogadhatatlannak bizonyult ( $a=0,444)$. Így ez a komponens nem került bele a véglegesített skálába, valamint az ehhez tartozó három tétel is kitörlésre került.

Három tétel töltési értéke nem csupán egy, hanem két faktor esetén és 0,4 fölött van. A végleges alskálák kialakítása során végül úgy döntöttünk, hogy a két komponens közül azt vesszük figyelembe, amelyik esetén a tétel töltési értéke nagyobb, ráadásul a tétel tartalmilag is szorosabban kapcsolódott ahhoz a faktorhoz, amelyiken magasabb töltésszámot mutatott.

Az így kialakított Párkapcsolati Identitás Kérdőív végleges formájában tehát 17 itemet tartalmaz. Az 1.hipotézist részben beigazolódottnak tekintjük, mivel a Marcia-féle elméleti keretnek megfelelően körvonalazódnak a különböző identitásállapotok: Keresés és kétség megfelel a moratóriumnak, a Családi mintakövetés a korai zárásnak, az Elköteleződés hiánya pedig a diffúzióra vonatkozik, ám az elvárásainkkal ellentétben az elért identitás itemei is negatív előjellel ide tagozódik. Az 5.táblázat tartalmazza a kérdőív tételeinek alskálák szerinti felosztását. 
5. táblázat. a PIK tételei alskálák szerinti felbontásban

\section{Elköteleződés halogatása (EH)}

Jelen pillanatban nem izgat, hogy akarok-e házasságot kötni, majd a jövőben gondolkodom rajta. Bár még nem világos számomra, hogy milyen párkapcsolati formában szeretnék élni, ez most még nem izgat.

Túl korai számomra, hogy a házasságkötés lehetőségén gondolkodjam.

Nincs határozott elképzelésem arról, hogy hogy alakul a magánéletem a jövőben, de nem is igazán érdekel.

Miután alaposan gondolkodtam a szóba jöhető párkapcsolati formákon, arra jutottam, hogy a házasság a lehető legjobb ezek közül.**

Arra a következtetésre jutottam, hogy szeretnék házasságot kötni a jövőben.*

Miután sokat töprengtem rajta, megbizonyosodtam arról, hogy szeretnék házasságot kötni.*

\section{Családi mintakövetés (CsM)}

Nem okoz hosszas töprengést, hogy milyen párkapcsolati formában szeretnék élni, mert a családi hagyományt követem.

Szeretnék megházasodni, mert a családomban ez a hagyomány.

A szüleim példája nyomán én is meg szeretnék házasodni.

Nem gondolkoztam túl sokat azon, hogy érdemes-e házasságot kötni, mert a szüleim már gyerekként erre neveltek.

Már gyermekkoromban eldöntöttem, hogy házasságot szeretnék kötni, soha nem gondoltam más lehetőségre.

\section{Keresés és kétség (KK)}

Sokat gondolkodom azon, hogy milyen párkapcsolati forma a legjobb számomra.

Az aktuális párkapcsolatom mellett nyitva tartom a szemem, és érdeklődöm más potenciális romantikus partnerek iránt is.

Próbálom eldönteni, hogy milyen párkapcsolati forma tudna boldoggá tenni hosszú távon, de még nem jutottam semmire.

Komolyan foglalkoztat, hogy megtalálom-e életem párját: sok kételyem van ezzel kapcsolatban. Jelenleg nem tudom pontosan, hogy kössek-e házasságot vagy sem; néha megfordul a fejemben a lehetőség.

* fordított tételek

\subsection{A kontruktumvaliditásra vonatkozó hipotézisek vizsgálata}

A skála konstruktumvaliditásának vizsgálatára alkalmaztuk a már fentebb ismertetett skálákat. A második hipotézis (2.) a kötődési stílusok, valamint a PIK alskálái közötti kapcsolatra vonatkozott. Az Elköteleződés halogatása (EH) alskála gyenge negatív korrelációt mutat a biztos kötődéssel $(r=-0,190 \mathrm{p}<0,01)$, ezzel szemben mérsékelt pozitív korrelációt az elkerülő kötődési mintával $(\mathrm{r}=0,336 \mathrm{p}<0,01)$. A Keresés és kétség $(\mathrm{KK})$ dimenzió szintén gyenge, negatív összefüggést mutat a biztos kötődéssel $(\mathrm{r}=-0,137 \mathrm{p}<0,01)$, ellenben mind az elkerülő kötődéssel ( $\mathrm{r}=0,340 \mathrm{p}<0,01)$, mind az ambivalens kötődéssel mérsékelt 
pozitív irányú kapcsolatot mutat $(\mathrm{r}=0,329 \mathrm{p}<0,01)$. A Családi mintakövetés (CsM) alskála ezzel ellentétben enyhe pozitív korrelációt mutat a biztos kötődéssel $(\mathrm{r}=0,151, \mathrm{p}<0,01)$, és negatív összefüggést az elkerülő kötődéssel ( $\mathrm{r}=-$ 0,188,p<0,01) (1.6.táblázat). A második hipotézist tehát beigazolódottnak tekintjük: a PIK alskálái gyenge, de szignifikáns összefüggést mutatnak a kötődési stílusokkal.

6. tábl. A PIK alskálái és a kötődési stílusok közti korrelációk

\begin{tabular}{lcccccc}
\hline & PIK-EH & PIK-KK & PIK-CsM & AAS-S & AAS-Av & AAS-Ax \\
\hline PIK-EH & - & - & - & - & - & - \\
PIK-KK & $0,534^{* *}$ & - & - & - & - & - \\
PIK-CsM & $-0,545^{* *}$ & $-0,267^{* *}$ & - & - & - & - \\
AAS-S & $-0,190^{* *}$ & $-0,137^{* *}$ & $0,151^{* *}$ & - & - & - \\
AAS-Av & $0,336^{* *}$ & $0,340^{* *}$ & $-0,188^{* *}$ & $-0,522^{* *}$ & - & - \\
AAS-Ax & 0,053 & $0,329^{* *}$ & 0,008 & $-0,228^{* *}$ & $0,331^{* *}$ & - \\
\hline
\end{tabular}

**. Correlation is significant at the 0.01 level (2-tailed).

A harmadik hipotézis (3.) az Élet Értelme Kérdőív (MLQ) és a PIK alskálái közötti kapcsolatra vonatkozott. Az Elköteleződés halogatása enyhe negatív kapcsolatban áll az értelmesség megélésével $(\mathrm{r}=-0,288 \mathrm{p}<0,01)$. A Keresés és kétség (KK) dimenzió szintén enyhe negatív kapcsolatban áll az értelem megélésével $(\mathrm{r}=-0,275 \mathrm{p}<0,01)$, ellenben az értelem keresésével gyenge pozitív korrelációt mutat $(\mathrm{r}=0,170 \mathrm{p}<0,01)$. A Családi mintakövetés dimenziója pedig mind az értelem megélésével $(\mathrm{r}=0,147 \mathrm{p}<0,05)$, mind az értelem keresésével gyenge pozitív kapcsolatban áll $(\mathrm{r}=0,117 \mathrm{p}<0,05)$ (lásd 7.tábl). A 3. hipotézist tehát szintén beigazolódottnak tekintjük.

7. tábl. A PIK alskálái és az Élet Értelme Kérdőív alskálái közti korrelációk

\begin{tabular}{lccccc}
\hline & PIK-EH & PIK-KK & PIK-CsM & MLQ-PM & MLQ-PS \\
\hline PIK-EH & - & - & - & - & - \\
PIK-KK & $0,534^{* *}$ & - & - & - & - \\
PIK-CsM & $-0,545^{* *}$ & $-0,267^{* *}$ & - & - & - \\
MLQ-PM & $-0,288^{* *}$ & $-0,275^{* *}$ & $0,147^{* *}$ & - & - \\
MLQ-PS & 0,019 & $0,170^{* *}$ & $0,117^{*}$ & $-0,179^{* *}$ & - \\
\hline
\end{tabular}

**. Correlation is significant at the 0.01 level (2-tailed).

*. Correlation is significant at the 0.05 level (2-tailed). 
Végül a negyedik hipotézis (4.) az elért identitás valamint az élettel való elégedettség összefüggésére vonatkozott. Az élettel való elégedettség enyhe negatív kapcsolatot mutat az Elköteleződés halogatásával ( $\mathrm{r}=-0,278 \mathrm{p}<0,01)$, valamint a Keresés és kétség dimenzióval is $(\mathrm{r}=-0,199 \mathrm{p}<0,01)$; ezzel szemben a Családi mintakövetés dimenzióval enyhén pozitív korrelációt ad $(\mathrm{r}=0,208 \mathrm{p}<0,01)$ (1.8.táblázat). A 4.hipotézist is beigazolódottnak tekinthetjük.

8. tábl. A PIK alskáláinak összefüggése az élettel való elégedettséggel

\begin{tabular}{lcccc}
\hline & PIK-EH & PIK-KK & PIK-CsM & SWLS \\
\hline PIK-EH & - & - & - & - \\
PIK-KK & $0,534^{* *}$ & - & - & - \\
PIK-CsM & $-0,545^{* *}$ & $-0,267^{* *}$ & - & - \\
SWLS & $-0,278^{* *}$ & $-0,199^{* *}$ & $0,208^{* *}$ & - \\
\hline
\end{tabular}

**. Correlation is significant at the 0.01 level (2-tailed).

Ötödik hipotézisünkben (5.) azt feltételeztük, hogy az életkor előrehaladtával a moratórium, valamint a diffúzió csökkenni fog. A hipotézis csupán részben igazolódott: az Elköteleződés halogatása gyenge negatív összefüggést mutat az életkorral $(\mathrm{r}=-0,167 \mathrm{p}<0,01)$, vagyis a diffúzió enyhén csökken az életkor előrehaladtával, ezzel szemben a Keresés és kétség tekintetében nem volt különbség a korcsoportok között $(\mathrm{r}=-0,017 \mathrm{p}=0,36)$, tehát a moratórium azonos szinten marad 19 éves kortól 29 éves kor fele haladva. Nemek szerinti bontás esetén viszont azt találtuk, hogy a nőknél az Elköteleződés halogatása enyhén csökken az életkor előrehaladtával $(r=-0,227 \mathrm{p}<0,01)$, míg férfiak esetén gyakorlatilag nincs szignifikáns lineáris kapcsolat a diffúzió és az életkor között ( $\mathrm{r}=$ $-0,084 \mathrm{p}=0,255)$.

A hatodik hipotézisben (6.) azt feltételeztük, hogy az egyes párkapcsolati identitásállapotok összefüggést mutatnak a vizsgálati személyek jelenlegi párkapcsolati státuszával. A feltevés vizsgálatára egyszempontos varianciaanalízist alkalmaztunk. A szóráshomogenitás a Családi mintakövetés (CsM), valamint a Keresés és kétség (KK) alskálák esetében teljesült, így itt az ANOVA tábla eredményét vettük figyelembe, ellentétben az Elköteleződés halogatása (EH) alskálával, ahol a szóráshomogentás nem teljesült, így a Welch statisztika eredményeivel számoltunk. Mind a három alskála esetén kimutathatók szignifikáns különbségek az aktuális párkapcsolati státusz függvényében, de ezek között csak egyes különbségek szignifikánsak (1. 9. tábl.). Az eredményekből látható, hogy a párkapcsolatban élő magasabb átlagot mutatnak az élettársi kapcsolatban élőkhöz képest a Családi mintakövetés $(\mathrm{CsM})$ tekintetében $(\mathrm{p}<0,05)$. Továbbá megfigyelhető, hogy az egyedülállók több pontszámot értek el a Keresés és két- 
ség (KK) alskálán mind a párkapcsolatban élőkhöz, mind az együttélőkhöz viszonyítva $(\mathrm{p}<0,01)$. Az Elköteleződés hiánya $(\mathrm{EH})$ tekintetében az egyedülállók szintén magasabb átlagot mutatnak a párkapcsolatban élőkhöz képest $(\mathrm{p}<0,01)$.

9. tábl. A PIK alskálái és a párkapcsolati státus közti összefüggések a varianciaanalízis tükrében

\begin{tabular}{lllcc}
\hline \multirow{2}{*}{ PIK alskálák } & \multicolumn{2}{c}{ Párkapcsolati státusz } & $\begin{array}{c}\text { Átlagok közti } \\
\text { külöbségek }\end{array}$ & p \\
\hline CsM & párkapcsolat & élettársi kapcsolat & 3,26 & 0,047 \\
\multirow{2}{*}{ KK } & egyedülálló & párkapcsolat & 3,13 & 0,000 \\
& egyedülálló & élettársi kapcsolat & 3,62 & 0,000 \\
EH & egyedülálló & párkapcsolat & 3,31 & 0,000 \\
\hline
\end{tabular}

Hetedik hipotézisünk (6.) a vallásgyakorlás rendszerességének, a vallás szubjektív fontosságának, valamint a PIK alskáláinak összefüggéseire vonatkozott. Az Elköteleződés halogatása dimenzió erős negatív korrelációt mutat a vallásosság mindkét vetületével $(r=-0,475, p<0,01$ és $r=-0,451 \mathrm{p}<0,01)$. Hasonlóképpen szignifikáns, de gyengébb negatív kapcsolat figyelhető meg a Keresés és kétség dimenziója és a vallásosság között $(\mathrm{r}=-0,268 \mathrm{p}<0,01$ és $\mathrm{r}=-0,264 \mathrm{p}<0,01)$. A Családi mintakövetés közepesen erős pozitív korrelációt mutat a vallásgyakorlás rendszerességével és a vallás szubjektív fontosságával $(\mathrm{r}=0,456 \mathrm{p}<0,01$ és $\mathrm{r}=0,392 \mathrm{p}<0,01$ ) (lásd 10.táblázat). A 6. hipotézist beigazolódottnak tekintjük.

10. tábl. A vallásosgyakorlás rendszeressége, a vallás szubjektív fontossága, valamint a PIK alskálái közti korrelációk

\begin{tabular}{lcc}
\hline & $\begin{array}{c}\text { Gyakorol-e valamilyen vallást, } \\
\text { és ha igen, milyen módon? }\end{array}$ & $\begin{array}{c}\text { Mennyire fontos Önnek a minden- } \\
\text { napi életben a vallás? }\end{array}$ \\
\hline PIK-EH & $-0,475^{* *}$ & $-0,451^{* *}$ \\
PIK-KK & $-0,268^{* *}$ & $-0,264^{* *}$ \\
PIK-CsM & $0,456^{* *}$ & $0,392^{* *}$ \\
\hline
\end{tabular}

**. Correlation is significant at the 0.01 level (1-tailed). 


\section{MEGBESZÉLÉS}

\subsection{A pszichometriai mutatók értelmezése}

A PIK tételeit a Melgosa-féle Pályaidentitás Skála alapján dolgoztuk ki, ezért hipotézisünkben feltételeztük, hogy a pályaidentitás skálához hasonlóan a tételek a Marcia-féle négy identitásállapot szerint fognak rendeződni. A főkomponens elemzés eredményeit áttekintve láthatjuk, hogy a tételek valóban négy faktor mentén helyezkednek el, ebből azonban az egyik megbízhatatlannak bizonyult. A megbízhatatlanság oka már a tételek csoportosulásán is látható: míg a másik három faktorba tartozó tételek a párkapcsolati formákkal és elköteleződéssel kapcsolatos álláspontokra kérdez rá, addig a 4. faktor három tétele tartalmilag inkább egy konkrét partnerrel szembeni viszonyulásra. Ez utóbbi faktor és tételei így nem kerültek bele a végleges kérdőívbe.

Az így megmaradt három faktor pedig megfeleltethető a Marcia-féle identitásállapotok mindegyikének: a második faktor (Családi mintakövetés) a korai zárást, a harmadik faktor (Keresés és kétség) pedig a moratóriumot méri. Az első faktor (az Elköteleződés halogatása) tételei tartalmilag két identitásállapotot is magába foglalnak: az identitásdiffúziót, valamint negatív előjellel az elért identitást. A faktoranalízis jelen esetben tehát tükrözi azt, amit Erikson és Marcia elmélete megfogalmaz: az érett identitás és az identitásdiffúzió egymással ellentétes pólusokként foghatók fel (Marcia, 1966).

Az egyes faktorok megbízhatósági mutatói jónak (Elköteleződés halogatása - $\mathrm{a}=0.864$, Családi mintakövetés - $\mathrm{a}=0.873$ ) illetve elfogadhatónak minősülnek (Keresés és késég - a=0.697). A skála tehát alkalmasnak bizonyul abból a szempontból, hogy a kevésbé érettnek minősülő identitásállapotokat (identitásdiffúzió, korai zárás, moratórium) differenciáltan mérje.

Érdemes megjegyezni, hogy az Elköteleződés halogatása faktor bír a legnagyobb „súllyal”, önmagában véve magyarázza a variancia több mint 21\%-át. Ez tény is alátámasztani látszik Arnett (2000) feltételezését, miszerint a „készülődő felnősség” időszakát ténylegesen a keresés és az elköteleződés hiánya, időbeni kitolása fémjelzi.

\subsection{A konstruktumvaliditásra vonatkozó eredmények értelmezése}

A konstruktumvaliditás vizsgálata szempontjából, más identitásvizsgálatokra alapozva (Palladino Shultheiss \& Bluestein, 1994; Ratner, 2014; Sheng, 2014) a kötődési stílust tekintettük az egyik legfontosabb konstruktumnak, ami összefüggést mutathat a párkapcsolati identitással. A kötődéselméletek szerint a biztos kötődés belső munkamodellje alapul szolgál az exploráció és a sikeres identitásalakulás számára, ezzel szemben a bizonytalan kötődés modelljei in- 
kább kevésbé érett identitásállapotok talaját képezik (Sheng, 2014). Az eredményeink alapján megállapítható, hogy az Elköteleződés halogatása alskála inkább az elkerülő kötődéssel, a Keresés és kétség alskála inkább az ambivalens és az elkerülő kötődéssel, a Családi mintakövetés alskála pedig a biztos kötődéssel mutat összefüggést. Az elkerülő kötédési minta részben magyarázatot adhat a párkapcsolati elköteleződési nehézségekre, és úgy tünik -amint egyes kutatások is rávilágítottak, hogy a biztos kötődési stílus nemcsak az érett identitással van összefüggésben, hanem hajlamosíthat a szülői minták automatikus átvételére, így a korai zárással is összefügg (Sheng, 2014). A két terület között található összefüggések azonban nem jelentős erősségűek, így óvatosan kell kezelnünk a kapott eredményeket. Valószínúbb, hogy a párkapcsolati identitás tekintetében nem kizárólag korai kötődési mintázat lenyomatának hatása érbényesül, hanem jelentős szerepe van az Arnett (2000) által említett társadalmi átalakulásoknak is.

A következő vizsgált összefüggés a párkapcsolati identitás, valamint az értelmességérzés kapcsolatára vonatkozott. A szakirodalommal összefüggésben (Schwarz és mtsai, 2011, 2013 stb) az élet értelmének megélése és az elért párkapcsolati identitás között, valamint az élet értelmének keresése és a moratórium között összefüggést vártunk. Elvárásaink lényegében beigazolódtak, mivel az Elköteleződés halogatása alskála negatív összefüggést mutat az élet értelmének megélésével, míg a Keresés és kétség alskála az értelem keresésével függ össze. A Családi mintakövetés alskála egyszerre mutat összefüggést az értelem megélésével és az értelem keresésével. Az eredmények arra engednek következtetni, hogy a diffúzióban lévő személyek, identitáselméleti megközelítésben egyik napról a másikra élnek, anélkül, hogy bizonyos életcélok, vagy életértelem vezérelné őket; a moratóriumban lévők helyzete egy általános kereséssel jellemezhető: egyszerre keresik önmagukat és olyan értékeket, életértelmet, amelyek mellett elköteleződhetnének. A korai zárók ugyan elköteleződtek bizonyos értékek mellett, ami értelmességérzést biztosít számukra, de valószínúleg amiatt, hogy ezeket nem érzik teljesen a sajátjuknak, az értelemkeresés nem zárult le életükben.

A párkapcsolati identitás és jóllét kapcsolatát illetően feltételeztük, hogy az érett identitás összefüggésben lesz az élettel való elégedettséggel. Az eredmények alapján a hipotézis beigazolódott: az Elköteleződés halogatása, valamint Keresés és kétség alskálák enyhe negatív összefüggésben állnak az élettel való elégedettséggel, míg a Családi mintakövetés szintén enyhe, pozitív összefüggésben áll ugyanezen konstruktummal. Eredményeink összhangban vannak a szakirodalommal, amely több ízben igazolta, hogy a diffúzió és moratórium alacsonyabb jólléti szintekkel társulnak, mint az elért identitás és a korai zárás (Schwarz és mtsai, 2011, 2013 stb). Ugyanakkor ez az összefüggés gyengének minősül, tehát az identitás mellett számos más tényező lehet kihatással az egyén jóllétére. 
Következő hipotézisünkben azt feltételeztük, hogy az életkor előrehaladtával csökkenni fog az identitásdiffúzióban, valamint a moratórium állapotában lévők száma (Cole \& Cole, 2006). A teljes mintára vetítve azt találtuk, hogy csupán az Elköteleződés hiánya alskála mutat szignifikáns negatív összefüggést az életkorral, tehát csak az identitásdiffúzió csökken, a moratórium állapota nem mutat csökkenést a 19-29 év között. Nemekre lebontva még érdekesebb összefüggést találtunk: csupán a nők esetén csökken az identitásdiffúzió, a férfiak esetén változatlan szinten marad 19-29 év között. Ezek az eredmények azt a tapasztalati tényt támasztják alá, hogy a nők az idő múlásával egyre inkább hajlanak a házassági elköteleződésre, míg a férfiak számára az idő múlása nem jelent nyomást a családalapítás szempontjából, legalábbis huszas éveikben még nem. A moratórium változatlan szintje 19-29 év között pedig arra utal, hogy a huszas évek vége fele is éppen olyan aktuális a magánéleti útkeresés, mint a serdülőkor végén. Mindez megerősíti Arnett (2000) elméletét miszerint a készülődő felnőttkor különálló időszak, amikor lehetőség van az elhúzódó explorációra szakmai és magánéleti téren egyaránt.

A párkapcsolati státusz és párkapcsolati identitás összefüggéseit illetően legjelentősebb eredmény, hogy az egyedülállók magasabb átlaggal rendelkeznek mind a Keresés és kétség, mind az Elköteleződés halogatása tekintetében, azokkal szemben, akik jelenleg párkapcsolattal rendelkeznek. Ez azt mutatja, hogy magánélete jövőjéről, valamint az elköteleződés kérdéséről nehezebb gondolkoznia elméletben annak, akinek aktuálisan nincs párkapcsolata. Ez a különbség felhívja figyelmünket arra, hogy vizsgálatunk szempontjából fontos külön kezelni e két populációt -az egyedülállókat, illetve a párkapcsolattal rendelkezőket.

Vizsgálatunkban a legerősebb - közepes erősségű - összefüggéseket a párkapcsolati identitás és a vallásosság között találhattuk meg. Hipotézisünkben feltételeztük, hogy az érett identitás és korai zárás - esetünkben a párkapcsolati elköteleződésre vonatkozó hajlandóság -, összefügg a vallásnak tulajdonított fontossággal, valamint a vallásgyakorlás rendszerességével, arra alapozva, hogy a vallásos nevelés alapvetően pozitív viszonyulást alakít ki a párkapcsolati elköteleződéssel szemben. Elvárásainkkal és a szakirodalommal összhangban (Markstrom, Hofstra \& Dougher, 1994), az eredmények azt mutatják, hogy az Elköteleződés halogatása alskála, valamint a Keresés és kétség alskála mérsékelt negatív összefüggésben áll mind a vallásnak tulajdonított fontossággal, mind a vallásgyakorlás rendszerességével, ezzel szemben a Családi mintakövetés alskála mérsékelt pozitív összefüggésben áll e kettővel. Úgy tűnik tehát, hogy azok a készülődő felnőttek, akik számára fontos a vallásgyakorlás (jelen esetben a korai zárók), szüleik példája nyomán határozták el jövőbeni párkapcsolati formájukat, házassággal kapcsolatos attitűdjeik sokkal pozitívabbak. Elképzelhető, hogy az identitás más szeletei nem mutatnának ilyen erősségú kapcsolatot a vallásossággal, de mivel a PIK kérdései konkrétan a párkapcsolati elkötelező- 
déssel kapcsolatos attitűdökre kérdezne rá, ezért itt egy szembetűnőbb kapcsolatot láthatunk.

\subsection{A kutatás korlátai}

A vizsgálati mintára elmondható, hogy egyértelműen torzít a 20-24 évesek, ezzel egyidejưleg a felsőoktatásban résztvevők irányába, 25-29 éves korosztály jelentôsen kisebb arányban képviselteti magát. Továbbá a teljes populációhoz viszonyítva a mintában túlreprezentáltak a vallást fontosnak tartó, és rendszeresen gyakorló személyek. A vizsgálat feltáró jellege miatt nem állt nagy számban rendelkezésre korábbi szakirodalom ebben a témában, így csekély viszonyítási alappal rendelkeztünk. Végül, de nem utolsó sorban, a különböző konstruktumterületek között szignifikáns, de csupán gyenge összefüggéseket kaptunk.

\section{KÖVETKEZTETÉS}

Elméleti szempontból azért tartjuk jelentősnek a Párkapcsolati Identitás Kérdőív létrejöttét, mivel ez az első mérőeszköz, ami az egyének párkapcsolati formákról alkotott elképzelését, elköteleződéssel kapcsolatos viszonyulását vizsgálja. A PIK megbízható mérőeszköznek bizonyult; a Marcia-féle identitás paradigma jól alkalmazható ezen a területen is. Úgy véljük, hogy a folytatásban érdemes lenne megvizsgálni milyen összefüggés van a párkapcsolati identitás, valamint az identitás más szeletei -elsősorban a pályaidentitás - között. Fontosnak tartanánk megvizsgálni a párkapcsolati identitás klinikai vetületeit, az alskálák összefüggéseit a depresszióval, szorongással.

Végül, de nem utolsó sorban, izgalmas kérdés, hogy vajon milyen családi háttértényezők állhatnak az identitásállapotok hátterében, amiért mondjuk valaki tartózkodik az elköteleződéstől - tehát hasznos lenne a származási család struktúrájának, a szülői nevelési stílusok feltárása.

Reméljük, hogy Párkapcsolati Identitás Kérdőív, valamint az ezzel végzett kutatások segítenek közelebb kerülni a készülődő felnőttség sajátosságainak további árnyalásához, és segíthet rávilágítani, hogy milyen tényezők állnak a párkapcsolati elköteleződés kitolódásának háttérben. 


\section{FÜGGELÉK}

\section{Párkapcsolati Identitás Kérdőív}

A következő állítások különböző viszonyulásokat fogalmaznak meg a párkapcsolattal, házassággal kapcsolatban. Kérem, hogy egy 1-től 5-ig terjedő skálán jelölje be, hogy mennyire tartja igaznak az alábbi állításokat a saját életére nézve!

1-egyáltalán nem igaz

2-inkább nem igaz

3-nem tudom eldönteni

4-inkább igaz

5- nagyon igaz

1. Jelenleg nem tudom pontosan, hogy kössek-e házasságot vagy sem; néha megfordul a fejemben a lehetőség.

$\begin{array}{lllll}1 & 2 & 3 & 4 & 5\end{array}$

2. Sokat gondolkodom azon, hogy milyen párkapcsolati forma a legjobb számomra.

3. Arra a következtetésre jutottam, hogy szeretnék házasságot kötni a jövőben.

4. Szeretnék megházasodni, mert a családomban ez a hagyomány.

5. Miután alaposan gondolkodtam a szóba jöhető párkapcsolati formákon, arra jutottam, hogy a házasság a lehető legjobb ezek közül.

6. Jelen pillanatban nem izgat, hogy akarok-e házasságot kötni, majd a jövőben gondolkodom rajta.

7. Már gyermekkoromban eldöntöttem, hogy házasságot szeretnék kötni, soha nem gondoltam más lehetőségre.

8. Az aktuális párkapcsolatom mellett nyitva tartom a szemem, és érdeklődöm más potenciális romatikus partnerek iránt is.

9. Túl korai számomra, hogy a házasságkötés lehetőségén gondolkodjam.

10. Próbálom eldönteni, hogy milyen párkapcsolati forma tudna boldoggá tenni hosszú távon, de még nem jutottam semmire.

(11. Ha nem látok perspektívát abban a párkapcsolatban, amiben vagyok, nem fogok sokat töprengeni azon, hogy kilépjek-e belöle. - faktoranalízis alapján kihagyva)

(12. Nem nyugszom addig, amíg meg nem találom életem párját. - faktoranalízis alapján kihagyva)

13. Nem gondolkoztam túl sokat azon, hogy érdemes-e házasságot kötni, mert a szüleim már gyerekként erre neveltek.

14. Nincs határozott elképzelésem arról, hogy hogy alakul a magánéletem a jövőben, de nem is igazán érdekel.

15. Miután sokat töprengtem rajta, megbizonyosodtam arról, hogy szeretnék házasságot kötni.
123345

$\begin{array}{lllll}1 & 2 & 3 & 4 & 5\end{array}$

$\begin{array}{lllll}1 & 2 & 3 & 4 & 5\end{array}$

123345

123345

12345

12345

12345

12345

12345

12345

12345

12345

12345 
16. Komolyan foglalkoztat, hogy megtalálom-e életem párját: sok kételyem van ezzel kapcsolatban.

17. Nem okoz hosszas töprengést, hogy milyen párkapcsolati formában szeretnék élni, mert a családi hagyományt követem.

(18. Szerintem az ember tegyen meg minden tőle telhetőt, hogy megtalálja élete párját. - faktoranalízis alapján kihagyva)

19. A szüleim példája nyomán én is meg szeretnék házasodni.

20. Bár még nem világos számomra, hogy milyen párkapcsolati formában szeretnék élni, ez most még nem izgat.

\section{IRODALOMJEGYZÉK}

75 papír-ceruza teszt. (dátum nélk.). Budapest: Animula Kiadó.

Andrási, Zs. (1995). Pszichológus hallgatók pályaidentitásának vizsgálata. Szakdolgozat. ELTE BTK, Budapest.

Arnett, J. J. (2000). Emerging adulthood: A theory of development from the late teens through the twenties. American Psychologist, Vol 55(5), 469-480.

Balistreri, E., Busch-Rossnagel, N. A. \& Geisinger, K. F. (1995). Development and preliminary validation of the Ego Identity Process Questionnaire. Journal of Adolescence 18, 179-192.

Bennion, L. D. \& Adams, G. R. (1986). A revision of the Extended Version of the Objective Measure of Ego-identity Status: An identity instrument for use with late adolescents. Journal of Adolescent Research, 1, 183-198.

Cole,M. \& Cole,S (2006): Fejlődéslélektan. Osiris, Budapest.

Collins, N. L. \& Read, S. J. (1990). Adult attachment, working models, and relationship quality in dating couples. Journal of Personality and Social Psychology, 58(4), 644-663.

Erikson, E. (1959). Identity and Life Cycle. New York: International Universities Press.

Faber,A., Edwards,A., Bauer, K. \& Wetchler, J. (2003): Family structure: its effect on adolescent attachment and identity formation. The American Journal of Family Therapy 31, 243-255.

Frankl, V. (2005): Az ember az értelemre irányuló kérdéssel szemben. Jel kiadó, Budapest.

Hazan, C \& Shaver,P.R. (1987): Romantic love conceptualized as an attachement process. Journal of Personality and Social Psychology 52, 511-524.

Horváth-Szabó Katalin (2007): A házasság és a család belső világa. Semmelweis Egyetem Mentálhigiéné Intézet, Budapest.

Kézdy, A. (2007). Fejlődési krízisek vizsgálata egyetemisták körében. In Z. Puskás-Vajda, Felsőoktatásban tanuló fiatalok problémái, útkeresése, pályafejlődése a 21. század kezdetén Magyarországon. Felsőoktatási Tanácsadás Egyesület, Budapest, 49-68.

Kiang, L.\& Fuligni, A. J. (2010). Meaning in Life as a Mediator of Ethnic Identity and Adjustment Among Adolescents from Latin, Asian, and European American Backgrounds. Journal of Youth and Adolescence 39 (11), 1253-1264. 
Kopp,M. \& Skrabski Á: Család és életminőség. In: Kopp,M. \& Kovács,M.E.(szerk.) (2006): A magyar népesség életminősége az ezredfordulón. Semmelweis kiadó, Budapest, 220-242.

Kroger,J. \& Marcia,J. (2011): The identity statuses: origins, meanings and interpretations. S.J.Schwartz et al. (eds.). Handbook of Identity Theory and Reasarch, 31-53.

Marcia, J. E. (1966). Development and Validation of Ego-Identity Status. Journal of Personality and Social Psychology Vol. 3, No. 5, 551-558.

Markstrom, A. C. (1999). Religious involvement and adolescent psychosocial development. Journal of Adolescence, 205-221.

Markstrom, A. C., Hofstra, G.\& Dougher, K. (1994). The ego-virtue of fidelity: A case for the study of religion and identity formation in adolescence. Journal of Youth and Adolescence, 453-469.

Martos, T. \& Konkoly-Thege, B. (2012). Aki keres, és aki talál - az élet értelmessége keresésének és megélésének mérése az élet értelme kérdőív magyar változatával. Magyar Pszichológiai Szemle, 67 (1), 125-149.

Martos, T., Sallay, V., Désfalvi, J., Szabó, T.\& Ittzés, A. (2014). Az Élettel való Elégedettség Skála magyar változatának (SWLS-H) pszichometriai jellemzõi. Mentálhigiéné és Pszichoszomatika 15 (3), 289-303.

Melgosa, J. (1987). Development and validation of the Occupational Identity Scale. Journal of Adolescence 10, 385-397.

Palladino-Schultheiss, D. P.\& Blustein, D. L. (1994). Contributions of Family Relationship Factors to the Identity Formation Process. Journal of Counseling \& Development, 73, 159-166.

Ratner, K. (2014). The Role of Parenting and Attachment in Identity Style Development. The University of Central Florida Undergraduate Research Journal, 7(1), 15-26.

Schwartz, S. J., Beyers, W., Luyckx, K., Soenens, B., Zamboanga, B. L., Forthun, L. F. et al. (2011). Examining the Light and Dark Sides of Emerging Adults' Identity: A Study of Identity Status Differences in Positive and Negative Psychosocial Functioning. Journal of Youth and Adolescence, 40, 839-859.

Schwartz, S.J., Zamboanga, B.L., Luyckx, K., Meca, A. \& Ritchie, R.A. (2013). Identity in Emerging Adulthood: Reviewing the Field and Looking Forward. Emerging Adulthood 1(2), 96-113.

Sheng, S. (2014): Attachement styles and identity status: az exploratory study. Research thesis, Ohio State University.

United Nations Economic Commission for Europe. (2013). Forrás: UNECE: http://w3.unece.org/ PXWeb/en/CountryRanking?IndicatorCode=303. Letöltve: 2016.05.10-én.

Takács Szabolcs (2016). Bevezetés a matematikai statisztikába, elmélet és gyakorlat, Budapest, Antarész Kiadó.

Takács Szabolcs (2012). Érzékenységvizsgálatok a statisztikai eljárásokban. Alkalmazott Matematikai Lapok, vol. 29, pp.:67-100.

Vargha András (2015). Matematikai Statisztika, Budapest, Pólya Kiadó. 